\title{
Anti-inflammatory and anti-amyloidogenic effects of a small molecule, 2,4-bis(p-hydroxyphenyl)-2-butenal in Tg2576 Alzheimer's disease mice model
}

Peng Jin ${ }^{1,2}$, Jin-A Kim ${ }^{1,2}$, Dong-Young Choi ${ }^{4}$, Young-Jung Lee ${ }^{5}$, Heon Sang Jung ${ }^{2,3}$ and Jin Tae Hong ${ }^{1,2^{*}}$

\begin{abstract}
Background: Alzheimer's disease (AD) is pathologically characterized by excessive accumulation of amyloid-beta $(A \beta)$ fibrils within the brain and activation of astrocytes and microglial cells. In this study, we examined anti-inflammatory and anti-amyloidogenic effects of 2,4-bis(p-hydroxyphenyl)-2-butenal (HPB242), an anti-inflammatory compound produced by the tyrosine-fructose Maillard reaction.

Methods: 12-month-old Tg2576 mice were treated with HPB242 (5 mg/kg) for 1 month and then cognitive function was assessed by the Morris water maze test and passive avoidance test. In addition, western blot analysis, Gel electromobility shift assay, immunostaining, immunofluorescence staining, ELISA and enzyme activity assays were used to examine the degree of $A \beta$ deposition in the brains of Tg2576 mice. The Morris water maze task was analyzed using two-way ANOVA with repeated measures. Otherwise were analyzed by one-way ANOVA followed by Dunnett's post hoc test.

Results: Treatment of HPB242 (5 mg/kg for 1 month) significantly attenuated cognitive impairments in Tg2576 transgenic mice. HPB242 also prevented amyloidogenesis in Tg2576 transgenic mice brains. This can be evidenced by A $\beta$ accumulation, BACE1, APP and C99 expression and $\beta$-secretase activity. In addition, HPB242 suppresses the expression of inducible nitric oxide synthase (iNOS) and cyclooxygenase-2 (COX-2) as well as activation of astrocytes and microglial cells. Furthermore, activation of nuclear factor-kappaB (NF-kB) and signal transducer and activator of transcription 1/3 (STAT1/3) in the brain was potently inhibited by HPB242.
\end{abstract}

Conclusions: Thus, these results suggest that HPB242 might be useful to intervene in development or progression of neurodegeneration in AD through its anti-inflammatory and anti-amyloidogenic effects.

Keywords: Alzheimer's disease, Amyloid-beta, NF-kB, STAT1/3, 2,4-bis(p-hydroxyphenyl)-2-butenal

\section{Background}

Alzheimer's disease (AD) is a fatal progressive neurodegenerative illness and the most common form of dementia [1]. AD is a devastating dementia that first presents as progressive memory loss and later can include neuropsychiatric symptoms [2]. Amyloidogenic processing of amyloid precursor protein (APP) by $\beta$ - and $\gamma$-secretases

\footnotetext{
*Correspondence: jinthong@chungbuk.ac.kr

${ }^{1}$ College of Pharmacy, Chungbuk National University, 12 Gaesin-dong,

Heungduk-gu, Cheongju, Chungbuk 361-763, Korea

${ }^{2}$ Medical Research Center, Chungbuk National University, 12 Gaesin-dong,

Heungduk-gu, Cheongju, Chungbuk 361-763, Korea

Full list of author information is available at the end of the article
}

leads to the production of $\mathrm{A} \beta$ peptides that can oligomerize and aggregate into amyloid plaques, a characteristic hallmark of $\mathrm{AD}$ [3]. Although the exact cause of $\mathrm{AD}$ remains elusive, mounting evidence continues to support the involvement of neuroinflammation in the development of AD [4]. Neuropathological studies in the human brain have demonstrated that the activated glial cells excessively release pro-inflammatory mediators and cytokines, which in turn triggerneurodegenerative cascades via neuroinflammation $[5,6]$. Inflammatory reactions and mediators have been reported to augment APP expression and $A \beta$ formation $[7,8]$ and transcriptionally 
upregulate mRNA and protein levels and enzymatic activity of $\beta$-secretase, a key enzyme in the production of A $\beta[9,10]$.

Astrocytes and microglia are the major type of glial cells in the central nervous system and activation of these cells are involved in all types of neurodegenerative processes, indicating prominent remodeling in $\mathrm{AD}$ [11,12]. Activated astrocytes expressing glial fibrillary acidic protein (GFAP) are closely associated with AD pathology, such as Tau tangles, neuritic plaques and amyloid depositions [13]. Furthermore, astrocytes with increased beta-secretase 1 (BACE1) expression have been found in the brain in $\mathrm{AD}$ [14]. Fibrillar $\mathrm{A} \beta$ can activate microglia, resulting in production of toxic and inflammatory mediators like hydrogen peroxide, nitric oxide, and cytokines [15]. Microglial cells are closely associated with nearly all compact deposits of the A $\beta$ protein found in the senile plaques of AD [16]. Microglial activation is also involved in neuroprotection in the early phase, but, subsequently, extensive and continuous activation of microglia results in the neuroinflammation and $\mathrm{A} \beta$ accumulation in $\mathrm{AD}$ pathology [17].

Nuclear factor-kappa B (NF- $\mathrm{kB})$ is a redox transcription factor that is critical for regulation of inflammation and various autoimmune diseases [12]. NF- $\mathrm{KB}$ is localized in the cytoplasm by the inhibitor of $\kappa B(\mathrm{I} \mathrm{B})$. After $\mathrm{I} \kappa \mathrm{B}$ is phosphorylated and degraded, NF- $\kappa B$ is released and translocated from the cytosol to the nucleus, and binds to its cognate DNA binding sites leading to expression of inflammatory mediators [18]. Expression of genes for inflammatory elements such as inducible inducible nitric oxide synthase (iNOS) and cyclooxygenase-2 (COX-2), as well as cytokines, can be regulated by activation of NF- $\kappa B$ [10]. NF- $k B$ activation was also found to promote neuronal resistance to $A \beta$ toxicity [19]. NF- $k B$ signaling increases BACE1 expression [20] and NF- $\mathrm{BB}$ inhibitors decrease $A \beta$ production and $\beta$-secretase activity [21]. Recently, it was reported that inhibition of the NF- $\mathrm{B}$ pathway could enhance $\alpha$-secretases, but inhibit $\beta$-secretase activity, and thereby reduce the formation of $A \beta$ [22]. Signal transducer and activator of transcription (STAT) 1 and STAT3 are also significant regulators of neuroinflammation, $A \beta$ generation [23] and cytokine-driven NF-кB-mediated $A \beta$ gene expression [24]. It was reported that resveratrol prevented the pro-inflammatory properties of fibrillar $A \beta$ on macrophages by potently inhibiting the effect of $A \beta$ on IkB phosphorylation, STAT1 and STAT3 activation [25]. Endogenous BACE1 levels were decreased by overexpression of suppressor of cytokine signaling (SOCS), an endogenous negative regulator of STAT1 signaling [26], demonstrating that downregulation of STAT1 signaling suppresses BACE1 expression and $A \beta$ generation in neurons [27]. STAT3 is another transcription factor that is typically associated with cytokine signaling during neuronal differentiation and inflammation [28]. The STAT3 patwhay is disrupted in neurodegeneration induced by amyloid-peptide [29]. The STAT3-mediated transcriptional control of BACE1 leads to amyloidogenic processing of APP and $A \beta$ generation [23].

The Maillard reaction (MR) products such as glucosetyrosine and xylose-arginine have antioxidant, antimutagenic, and antibacterial effects [30-32]. Our previous studies have shown the fructose-tyrosine MR product, HPB242, inhibits lipopolysaccharide (LPS)-elevated A $\beta$ levels in cultured astrocytes and microglial BV-2 cells through attenuation of LPS-induced neuroinflammatory reactions [10]. Therefore, in the present study, we investigated whether HPB242 improves memory function and inhibits amyloidogenesis via the prevention of neuroinflammation in $\operatorname{Tg} 2576$ mice.

\section{Methods}

Animals

In the present study we used $\operatorname{Tg} 2576$ mice as a model of AD. These mice overexpress human APP with the Swedish double mutations (K670N, M671L) under the control of a hamster prion protein promoter [33]. The 12-month-old $\operatorname{Tg} 2576$ female mice used in the present study were purchased from Taconic Farms (Germantown, NY, USA) and were maintained and handled in accordance with a protocol approved by the Institutional Animal Care and Use Committee of Laboratory Animal Research Centre at Chungbuk National University (Approval no. CBNU144-1001-01).

\section{Chemicals}

Characterization of HPB242 has been described elsewhere [34]. In brief, we prepared $100 \mathrm{ml}$ of fructosetyrosine mixture including $0.1 \mathrm{M}$ tyrosine and $0.05 \mathrm{M}$ fructose. MR was carried out in temperature-controlled autoclave apparatus (Jisico, Seoul, South Korea) at $130^{\circ} \mathrm{C}$ for $2 \mathrm{hr}$. After $2 \mathrm{hr}$ heating, the reaction mixture was filered through a $0.45 \mu \mathrm{m}$ membrane and used to isolate the active compounds through several fractionation steps. Fructose-tyrosine MR products were purified using a series of solvent fractionations; ethyl acetate (EtOAc), n-butanol, and water. The EtOAc fraction was subjected to silica gel column chromatography and eluted with increasing concentrations of methanol $(\mathrm{MeOH})$ in dichloromethane (DCM). An A2 fraction via DCM: $\mathrm{MeOH}(20: 1, \mathrm{v}: \mathrm{v})$ of a first silica gel chromatography was separated to 23 sub-fractions via a second silica gel chromatography. Fractions B14 and B15 from the 23 sub-fractions were further purified by semi-preparative high performance liquid chromatography with a $\mathrm{C} 18$ column. The structure is shown in Figure 1A. Then 2,4-Bis 


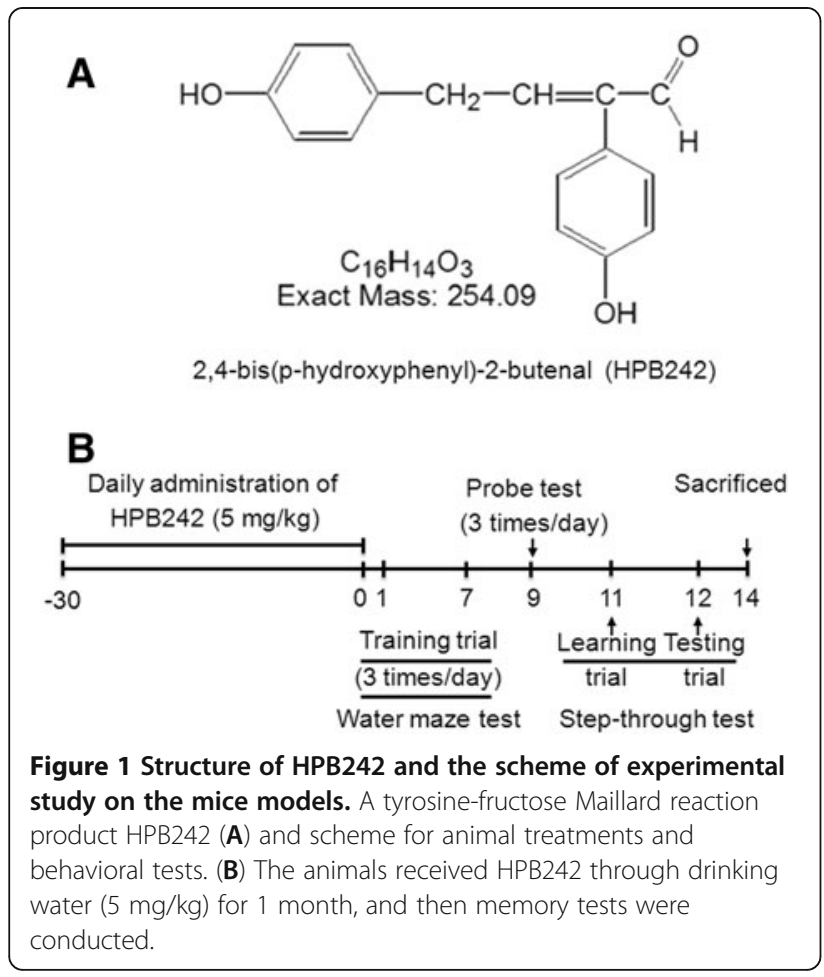

(phydroxyphenyl)-2-butenal was given to Tg2576 mice ( $\mathrm{n}=8$ in each group) in drinking water at the dose of $5 \mathrm{mg} / \mathrm{kg}$ for 1 month.(Figure $1 \mathrm{~B}$ ).

\section{Morris water maze test}

The Morris water maze test is a widely accepted method for examining cognitive function and was used in the present study as described previously [35]. Briefly, a circular plastic pool (height $35 \mathrm{~cm}$, diameter $100 \mathrm{~cm}$ ) was filled with water (plus white dye) maintained at 22 to $25^{\circ} \mathrm{C}$. An escape platform (height $14.5 \mathrm{~cm}$, diameter $4.5 \mathrm{~cm}$ ) was submerged 0.5 to $1 \mathrm{~cm}$ below the surface of the water. The test was performed three times a day for 7 days during the acquisition phase (days 1 to 7), with three randomized starting points. The position of the escape platform was kept constant. Each trial lasted for $60 \mathrm{~s}$ or ended as soon as the mice reached the submerged platform. The swimming pattern of each mouse was monitored and recorded by a camera mounted above the center of the pool, and the escape latency, escape distance and swimming speed were assessed by the SMART-LD program (Panlab, Barcelona, Spain). A quiet environment, consistent lighting, constant water temperature and a fixed spatial frame were maintained throughout the experimental period.

\section{Probe test}

To assess memory consolidation, a probe test was performed $48 \mathrm{hr}$ after the water maze test (on day 9). For the probe test, the platform was removed from the pool and the mice were allowed to swim freely. The swimming pattern of each mouse was monitored and recorded for 60s using the SMART-LD program (Panlab). Consolidated spatial memory was estimated by the time spent in the target quadrant area.

\section{Passive avoidance test}

The passive avoidance response was determined using step-through apparatus (Med Associates, Georgia, VT, USA). At $48 \mathrm{hr}$ after the probe test (on day 11), a training trial was performed. To this end, each mouse was placed in the illuminated compartment of the apparatus facing away from the dark compartment. When the mouse moved completely into the dark compartment, it received an electric shock ( $0.45 \mathrm{~mA}, 3 \mathrm{~s}$ duration). At $24 \mathrm{hr}$ after the training trial (on day 12), each mouse was placed in the illuminated compartment and the latency period until it entered the dark compartment was determined and defined as the step-through latency. The cut-off time for the examination was 180 s.

\section{Collection and preservation of brain tissues}

At $48 \mathrm{hr}$ after the passive avoidance test, mice were anesthetized with diethyl ether and then perfused with PBS. The brains were immediately removed from skull, and the cortex and hippocampus were dissected on ice. All brain tissues were stored at $-80^{\circ} \mathrm{C}$ until biochemical analysis.

\section{Immunohistochemical staining}

After being anesthetized with diethyl ether, subgroups of mice were perfused intracardially with $50 \mathrm{~mL}$ saline. The brains were removed from the skull and post-fixed in $4 \%$ paraformaldehyde for $24 \mathrm{~h}$ at $4^{\circ} \mathrm{C}$. The brains were transferred to $30 \%$ sucrose solutions. Subsequently, brains were cut into $30 \mu \mathrm{m}$ sections by using cryostat microtome (Leica CM1850; Leica Microsystems, Seoul, Korea). After multiple washing in PBS, endogenous peroxidase activity was quenched by incubation of the samples in 3\% hydrogen peroxide in PBS for 30 minutes, followed by a 10-minutes wash in PBS. Sections were then incubated for $2 \mathrm{~h}$ at room temperature with a mouse polyclonal antibody against $A \beta$ (1:5000; Covance, Berkeley, CA, USA), a rabbit polyclonal antibody against GFAP and iNOS (1:1000; Abcam, Inc, Cambridge, MA, USA), a rabbit polyclonal antibody against COX-2 (1:1000; Cayman, Ann Arbor, MI, USA) and a rabbit polyclonal antibody against ionized calcium binding adaptor molecule 1 (Iba1) (1:1000; Wako, Osaka, Japan). After incubation with the primary antibodies, sections were washed in PBS before being incubated for $1 \mathrm{~h}$ at room temperature in the presence of biotinylated goat anti-rabbit or anti-mouse IgG secondary antibodies (1:1000; Vector Laboratories, 
Burlingame, CA, USA). Sections were then washed with PBS and incubated with avidin-peroxidase complex (Vector Laboratories) for 30 minutes before the immunocomplex was visualized using the chromogen 3,3'-diaminobenzidine (Vector Laboratories). Sections were then counterstained with hematoxylin. Finally, sections were dehydrated in ethanol, cleared in xylene and covered with Permount ( $\mathrm{n}=8$ mice per group).

\section{Immunofluorescence staining}

The brain-tissue processing methods were the same as described above (Immunohistochemical staining). The mouse brain sections were incubated for $2 \mathrm{~h}$ at room temperature with a goat polyclonal antibody against p50 (1:500, Santa Cruz Biotechnologies, Inc., Santa Cruz, CA, USA), a rabbit monoclonal antibodies against Iba1 (1:1000; Wako, Osaka, Japan) and a rabbit monoclonal antibodies against GFAP (1:1000; Abcam). After washing with PBS, the brain sections were incubated with an anti-rabbit or anti-mouse secondary antibody labeled with Alexa-Fluor 488 and Alexa-Fluor 568 (1:800 Invitrogen, Paisley, UK) for $2 \mathrm{~h}$ at room temperature. Sections were then dehydrated in ethanol, cleared in xylene and covered with Permount. Final images were acquired using a confocal laser scanning microscope (TCS SP2, Leica Microsystems AG, Werzlar, Germany).

\section{Western blot analysis}

Western blot analysis was performed with the hippocampus or cortex dissected and stored at $-80^{\circ} \mathrm{C}$. The brain tissues were homogenized with lysis buffer (PROPREP; iNtRON, Sungnam, Korea; $\mathrm{n}=8$ mice per group) and centrifuged at $2500 \times \mathrm{g}$ for 15 minutes at $4^{\circ} \mathrm{C}$. Equal amounts of total protein $(40 \mu \mathrm{g})$ isolated from brain tissues were resolved on $8 \%$ or $10 \%$ sodium dodecyl sulphate polyacrylamide gels and then transferred to nitrocellulose membranes (Hybond ECL; Amersham Pharmacia Biotech, Piscataway, NJ, USA). Membranes were incubated at room temperature for $2 \mathrm{~h}$ with the following specific antibodies: anti-BACE1 (1:500; Sigma, St Louis, MO, USA), anti-APP (1:500; Sigma), anti-iNOS, anti-GFAP (both 1:1000; Abcam), anti-Iba1 (1:1000; Wako), anti-COX-2 (1:1000; Cayman), anti-p50, anti-p65, anti-IкB, anti-p-IкB, anti-STAT1/3, anti-p-STAT1/3 (all diluted 1:500, Santa Cruz Biotechnologies) and anti- $\beta$-actin (1:2500; Sigma). Blots were then incubated at room temperature for $2 \mathrm{~h}$ with corresponding peroxidaseconjugated anti-mouse or anti-rabbit antibodies (1/2000; Santa Cruz). Immunoreactive proteins were detected using an enhanced chemiluminescence (ECL) western blotting detection system. The relative density of the protein bands was scanned densitometrically using My Image (SLB, Seoul, Korea) and quantified by Lab Works 4.0 (UVP, Upland, CA, USA).

\section{Gel electromobility shift assay (EMSA)}

Gel shift assays were performed according to the manufacturer's recommendations (Promega, Madison, WI, USA). Briefly, brain tissues (100 mg) were suspended in $200 \mu \mathrm{l}$ of solution A (1 M HEPES ( $\mathrm{pH} 7.9), 0.15 \mathrm{M}$ $\mathrm{MgCl}_{2}, 1 \mathrm{M} \mathrm{KCl}, 100 \mathrm{mM}$ dithiothreitol, $0.5 \%$ Nonidet P-40, 0.1\% Protase Inhibitor (Sigma), 0.1\% Phosphatase Inhibitor (Sigma) and $100 \mathrm{mM}$ phenylmethylsulfonyl fluoride). Tissues were then allowed to incubate on ice for 6 minutes and were centrifuged at $8000 \mathrm{rpm}$ for 8 minutes. The pelleted nuclei were resuspended in solution $\mathrm{C}$ (solution $\mathrm{A}+(5 \mathrm{M} \mathrm{NaCl}, 20 \mathrm{mM}$ ethylenediamine tetraacetic acid anticoagulant (EDTA), 20\% glycerol)-(Nonidet P-40, 1 $\mathrm{M} \mathrm{KCl})$ ) and allowed to incubate on ice for 20 minutes. The tissues were centrifuged at $15000 \mathrm{rpm}$ for 15 minutes, and the resulting nuclear extract supernatant was collected in a chilled Eppendorf tube. Consensus oligonucleotides were endlabeled using $\mathrm{T} 4$ polynucleotide kinase and $\left(\gamma-{ }^{32} \mathrm{P}\right)$ ATP for 10 minutes at $37^{\circ} \mathrm{C}$. Gel shift reactions were assembled and allowed to incubate at room temperature for 10 minutes followed by the addition of $1 \mu \mathrm{L}$ (50,000 to $200,000 \mathrm{rpm})$ of ${ }^{32} \mathrm{P}$ endlabeled oligonucleotide and another 20 minutes of incubation at $37^{\circ} \mathrm{C}$. Subsequently $1.5 \mu \mathrm{L}$ of gel loading buffer was added to each reaction and loaded onto a $6 \%$ non-denaturing gel, and electrophoresis was performed until the dye was four fifths of the way down the gel. The gel was dried at $80^{\circ} \mathrm{C}$ for $2 \mathrm{~h}$ and exposed to film overnight at $-70^{\circ} \mathrm{C}$. The relative density of the protein bands was scanned by densitometry using MyImage (SLB, Seoul, Korea), and quantified by Labworks 4.0 software (UVP Inc.).

\section{Measurement of $A \beta_{1-42}$}

A specific ELISA kit (Immuno-Biological Laboratories, Gunma, Japan) was used to determine A $\beta$ (1 to 42) levels. Protein was extracted from brain tissue using lysis buffer containing protease inhibitors and centrifuged $2500 \times \mathrm{g}$ for 15 minutes at $4^{\circ} \mathrm{C}$. The supernatant was collected. Briefly, $100 \mu \mathrm{L}$ aliquots of brain tissue samples (total protein $100 \mu \mathrm{g}$ ) from eight mice in each group were added to pre-coated plates and incubated overnight at $4^{\circ} \mathrm{C}$. After washing each well seven times with washing buffer, 100 $\mu \mathrm{L}$ chromogen-labeled antibody solution was added and the mixture was incubated for $1 \mathrm{~h}$ at $4^{\circ} \mathrm{C}$ in the dark. After washing each well nine times with washing buffer, $100 \mu \mathrm{L}$ chromogen was added and the mixture was incubated for 30 minutes at room temperature in the dark. Finally, after added $100 \mu \mathrm{L}$ stop solution, the resulting color was assayed at $450 \mathrm{~nm}$ using a microplate reader (Sunrise; TECAN, Mannedorf, Switzerland).

\section{Measurement of $\beta$-secretase}

$\beta$-secretase activity in Tg2576 mice brains was determined using a commercially available $\beta$-secretase activity 
kit (Abcam). Protein was extracted from brain tissue using ice-cold extraction buffer, incubated on ice 20 minutes and centrifuged $10000 \times \mathrm{g}$ for 5 minutes at $4{ }^{\circ} \mathrm{C}$. The supernatant was collected. A total of $50 \mu \mathrm{L}$ of sample (total protein $100 \mu \mathrm{g}$ ) was added to each well followed by $50 \mu \mathrm{L}$ of $2 \times$ reaction buffer and $2 \mu \mathrm{L}$ of beta-secretase substrate incubated in the dark at $37^{\circ} \mathrm{C}$ for $2 \mathrm{hr}$. Fluorescence was read at excitation and emission wavelengths of 355 and $510 \mathrm{~nm}$ respectively, using a Fluostar Galaxy fluorimeter (BMG Lab Technologies, Offenburg, Germany) with Felix software (BMG Lab Technologies, Offenburg, Germany). Beta-secretase activity is proportional to the fluorimetric reaction, and is expressed as nmol/mg protein per minute.

\section{Statistical analysis}

All statistical analysis was performed with GraphPad Prism 4 software (Version 4.03; GraphPad software, Inc., San Diego, CA, USA). Group differences in the escape distance, latency, and velocity in the Morris water maze task were analyzed using two-way analysis of variance (ANOVA) with repeated measures, the factors being treatment and testing day. Otherwise, data were analyzed by one-way ANOVA followed by Dunnett's post hoc test. All values are presented as mean \pm standard error of the mean (SEM). Significance was set at $P<0.05$ for all tests.

\section{Results \\ Inhibition of memory impairment in Tg2576 mice by HPB242}

To investigate the preventive effect of HPB242 against memory impairment and $A \beta_{1-42}$ depositions in the $A D$ model mice, we treated 12-month old Tg2576 transgenic mice with HPB242 for 1 month, and then compared memory deficiency with the non-treated mice using the water maze test. The Tg2576 mice were trained for three trials per day for 7 days. Escape latency and escape distances, which are the time and distance travelled to reach the platform in the water maze, were measured to determine the memory-improving effect of HPB242. The mice exhibited shorter time and shorter escape latency with the training, however, the escape latency of $\operatorname{Tg} 2576$ mice was not much reduced compared to the nontransgenic mice. Oral treatment with HPB242 (5 mg/kg) for 1 month significantly ameliorated memory dysfunction in the AD model mice. Statistical analysis of data from day 5 showed a significant memory-improving effect of HPB242 treatment. Escape latency $(F(1,15)=9.61$, $P<0.05$ (treatment-wise) $)(F(6,15)=12.83, P<0.05$ (day-wise)) of the treated group was shorter than that of the non-treated group (Figure 2A). Escape distance $(F(1,15)=10.31, P<0.05$ (treatment-wise); $F(6,15)=$ $5.51, P<0.05$ (day-wise)) was also reduced by the treatment (Figure 2B). However, there was no significant difference in average speed between the non-treated and the HPB242treated group (data not shown).

After the water maze test, we performed a probe test to analyze maintenance of memory. During the probe test, the time spent in the target quadrant by the $\mathrm{Tg} 2576$ mice group treated with HPB242 (18.78 \pm 4.72 s) was significantly increased compared with the non-treated group $(36.87 \pm 8.14 \mathrm{~s})(F(1,15)=207.84, P<0.05)$ (Figure $2 \mathrm{C}$ ). In particular, the time spent by HPB242treated $\operatorname{Tg} 2576$ mice was similar to the time spent by non-transgenic mice $(27.31 \pm 10.73 \mathrm{~s})$.

We then evaluated learning and memory capacities by the passive avoidance test using the step-through method. In the passive avoidance test, there was no significant difference on the learning trial. However, in the test trial, Tg2576 mice treated with the HPB242 significantly increased the step-through latency (173.33 $\pm 36.56 \mathrm{~s})$ compared with the non-treated transgenic mice (100.16 \pm $32.49 \mathrm{~s})(F(1,15)=11.26, P<0.05)$ (Figure $2 \mathrm{D})$.

\section{Effect of HPB242 on $A \beta$ accumulation and amyloidogenesis in brains of Tg2576 AD mice}

Several studies reported that $A \beta$ accumulation, which is thought to be a major cause of $\mathrm{AD}$, occurred in the brain of Tg2576 mice. Hence, we investigated whether HPB242 attenuated $A \beta$ accumulation in the brains of $\mathrm{Tg} 2576$ mice. Immunohistochemical analyses using $A \beta_{1-42}$-specific antibodies revealed clearly the $A \beta$ deposition in the cortex and hippocampus of non-treated Tg2576 mice. In contrast, there appeared to be reduced $A \beta$ accumulation in the brains of HPB242-treated Tg2576 mice, as evidenced by a decrease in the number of $A \beta$ plaques (Figure $3 \mathrm{~A}$ ). To determine whether the degree of $A \beta$ deposition is paralleled with $A \beta$ protein levels in the brain, quantitative analysis of $A \beta_{1-42}$ levels was performed using an $A \beta_{1-42}$-specific ELISA kit. As shown in Figure $3 B$, HPB242 treatment reduced $A \beta_{1-42}$ levels in the brain of $\mathrm{Tg} 2576$ mice. In addition, to evaluate $\beta$-secretase activity (BACE1) we performed ELISA, and western blot analysis was performed to quantify $\beta$-secretase activity, APP and BACE1. ELISA analysis revealed that $\beta$-secretase activity was significantly reduced by treatment with HPB242 in the brain of Tg2576 mice (Figure 3C). Western blot analysis also revealed that APP, C99 and BACE1 levels were significantly decreased in both the cortex and hippocampus of HPB242-treated mice compared with non-treated mice (Figure 3D).

\section{Effect of HPB242 on activation of astrocytes and microglia, and expression of iNOS and COX-2 in the Tg2576 mice brain}

It has also been reported that activation of astrocytes and microglia is one of the characteristic features of $\mathrm{AD}$; these can produce pro-inflammatory cytokines as 

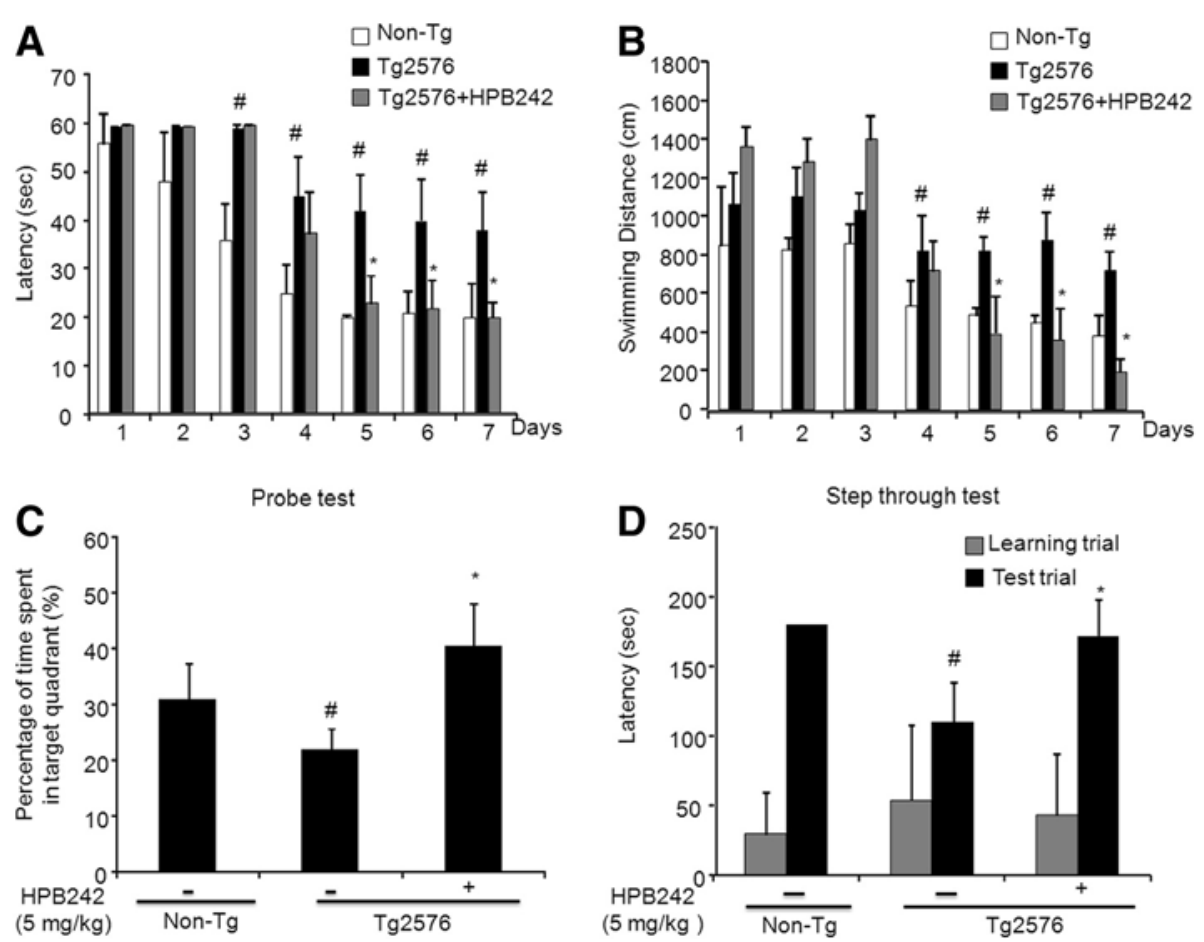

Figure 2 Effect of HPB242 on improvement of memory impairment in Tg2576 mice. The training trial was performed three times a day for 7 days. Swimming time (A) and swimming distance (B) to the platform were automatically recorded. Two days after the training trials, a probe test was performed. The time spent in the target quadrant and target site crossing within $60 \mathrm{~s}$ was represented (C). Each value is presented as mean \pm standard error of the mean (SEM) from eight mice. To perform the passive avoidance test, mice were given an electric shock on entering the dark compartment for training on the learning day. After 2 days, the retention time in the illuminated compartment was recorded (D). Each value is presented as mean \pm SEM from eight mice. \#Significantly different to non-Tg mice $(P<0.05)$, *Significantly different to non-treated Tg2576 mice $(P<0.05)$.

well as generate $A \beta$ on activation. We thus examined activation of astrocytes and microglia in the brains of HPB242-treated and non-treated $\operatorname{Tg} 2576$ mice. In the results, GFAP-reactive cell number (activated astrocytes) and Iba1-reactive cell number (microglia) was reduced in the brains of HPB242-treated $\operatorname{Tg} 2576$ mice compared to those of non-treated $\operatorname{Tg} 2576$ mice (Figure 4A and B). To confirm these results, we investigated the expression of GFAP and Ibal by western blot analysis. The results revealed that GFAP and Iba1 levels were significantly decreased in both the cortex and hippocampus of HPB242-treated compared with non-treated mice (Figure $4 \mathrm{C}$ ). We also investigated the inhibitory effect of HPB242 on memory impairment and $A \beta$ deposition via inhibition of neuroinflammation; the expression of iNOS and COX-2 were determined by immunohistochemical analysis and western blot. Expression of the inflammatory protein such as iNOS and COX-2 in brain of Tg2576 mice were significantly decreased by treatment of HPB242 (Figure 4D, E and F).

\section{Effect of HPB242 on NF-KB transcriptional and DNA} binding in the brain of Tg2576 mice

Since NF- $k B$ is implicated for $A \beta$ generation and neuroinflammatory reaction, we determined NF- $\kappa B$ DNA binding activity and expression of $\mathrm{p} 50$ and p65, submits of NF- $\mathrm{kB}$. The analysis of NF- $k B$ translocation on the Tg2576 mouse brain was performed by confocal microscopy. From confocal microscopy analysis, we found that HPB242 prevented NF- $\mathrm{kB}$ translocation from cytoplasm to nucleus in the microglia and astrocytes of the $\operatorname{Tg} 2576$ mouse brain (Figure 5A and B). Moreover, to confirm this detail, we also investigated the effects of HPB242 on NF- $\mathrm{kB}$ activation in $\operatorname{Tg} 2576$ mice. This DNAbinding activity of NF-kB confirmed by EMSA analysis was inhibited by HPB242 (Figure 5C). The levels of cytoplasmic phosphorylated IKB, nuclear translocation of p50 and p65 were also inhibited by treatment with HPB242 (Figure 5D).

\section{Effect of HPB242 on STAT1 and STAT3 activities}

In the nucleus, STATs and NF- $\mathrm{kB}$ regulate the activity of genes whose products are critical in controlling numerous 


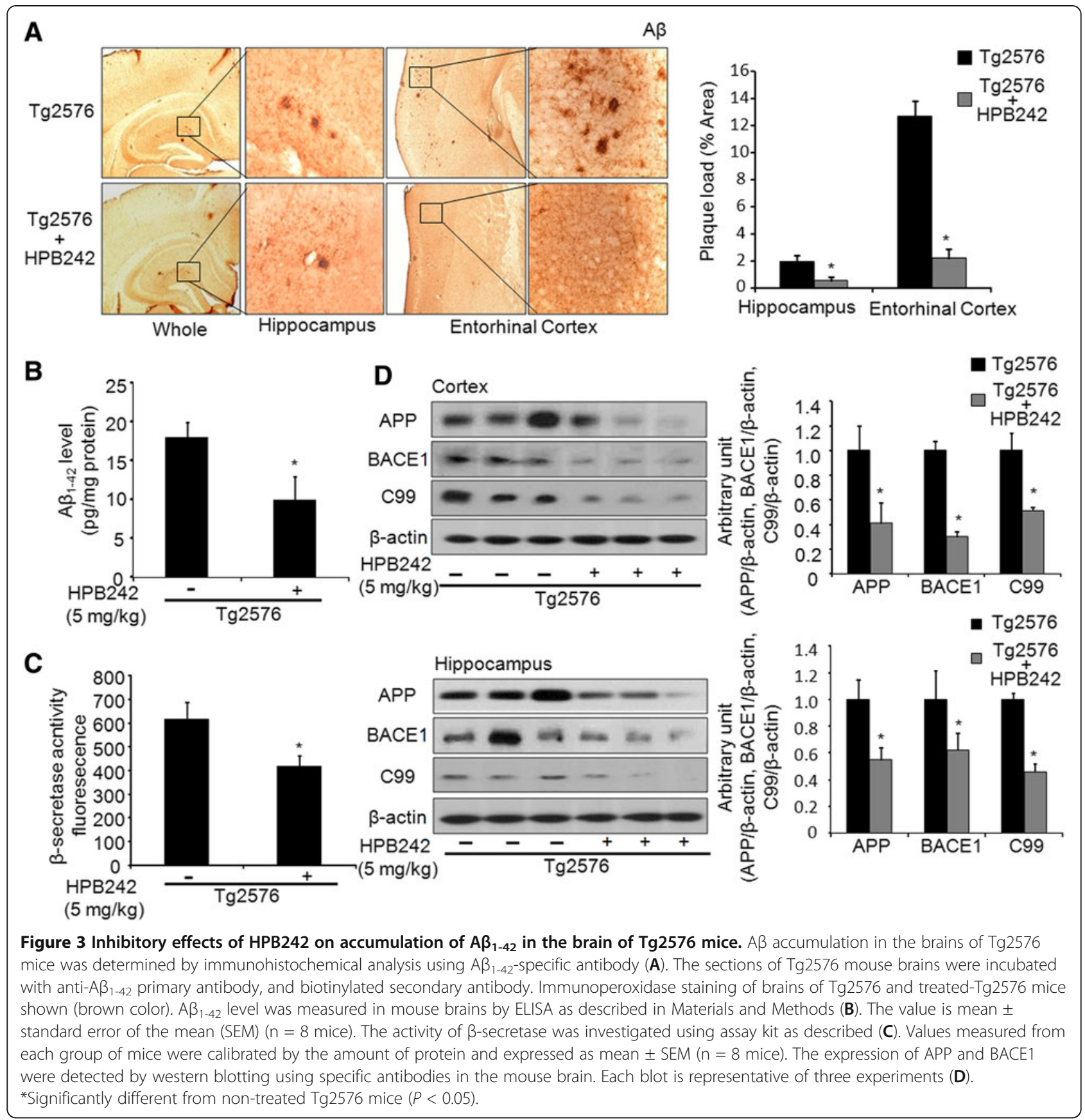

cellular and organismal processes, including inflammatory responses and $A \beta$ deposition in the brain in. We investigated whether HPB242 can prevent activation of STAT1 and STAT3 in the brain of Tg2576 mice. Our results showed that the DNA bingding ability of STAT1 and STAT3 was inhibited by HPB242 performed by EMSA (Figure 6A). Western blot analysis revealed that p-STAT1 and p-STAT3 levels were significantly decreased in the whole brain of HPB242-treated Tg2576 mice compared with non-treated Tg2576 mice (Figure 6B).

\section{Discussion}

Accumulating epidemiological evidence has suggested that neuroinflammation may contribute to the occurrence and progression of AD [36-38]. The brains of patients with $\mathrm{AD}$ appear to display enhancement of hallmarks of neuroinflammation, including marked astrogliosis, and elevated release of proinflammatory mediators and cytokines, as well as microglial activation [6]. Indeed, neuroinflammation has been reported to cause amyloidogenesis in several AD animal models. For example, 


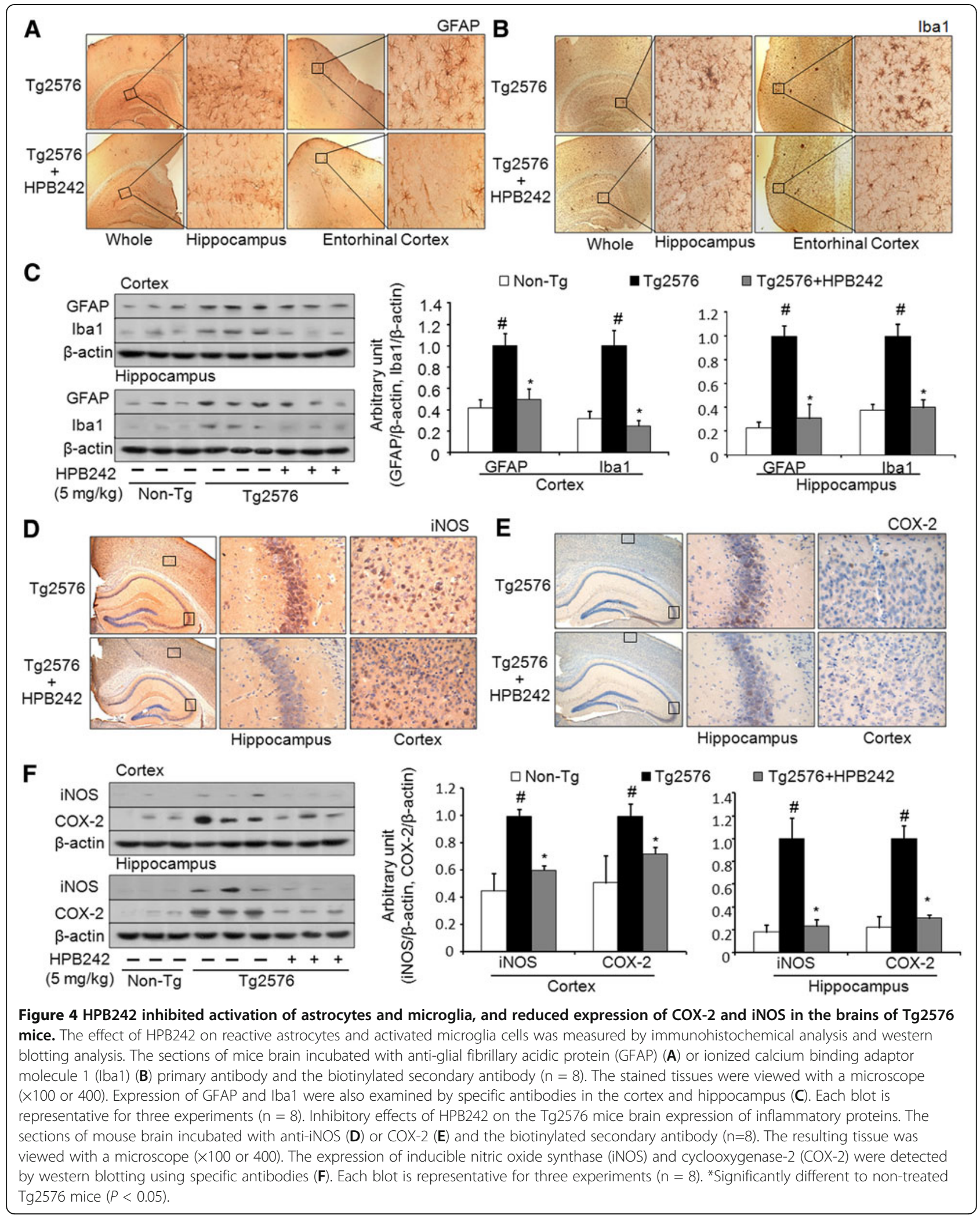




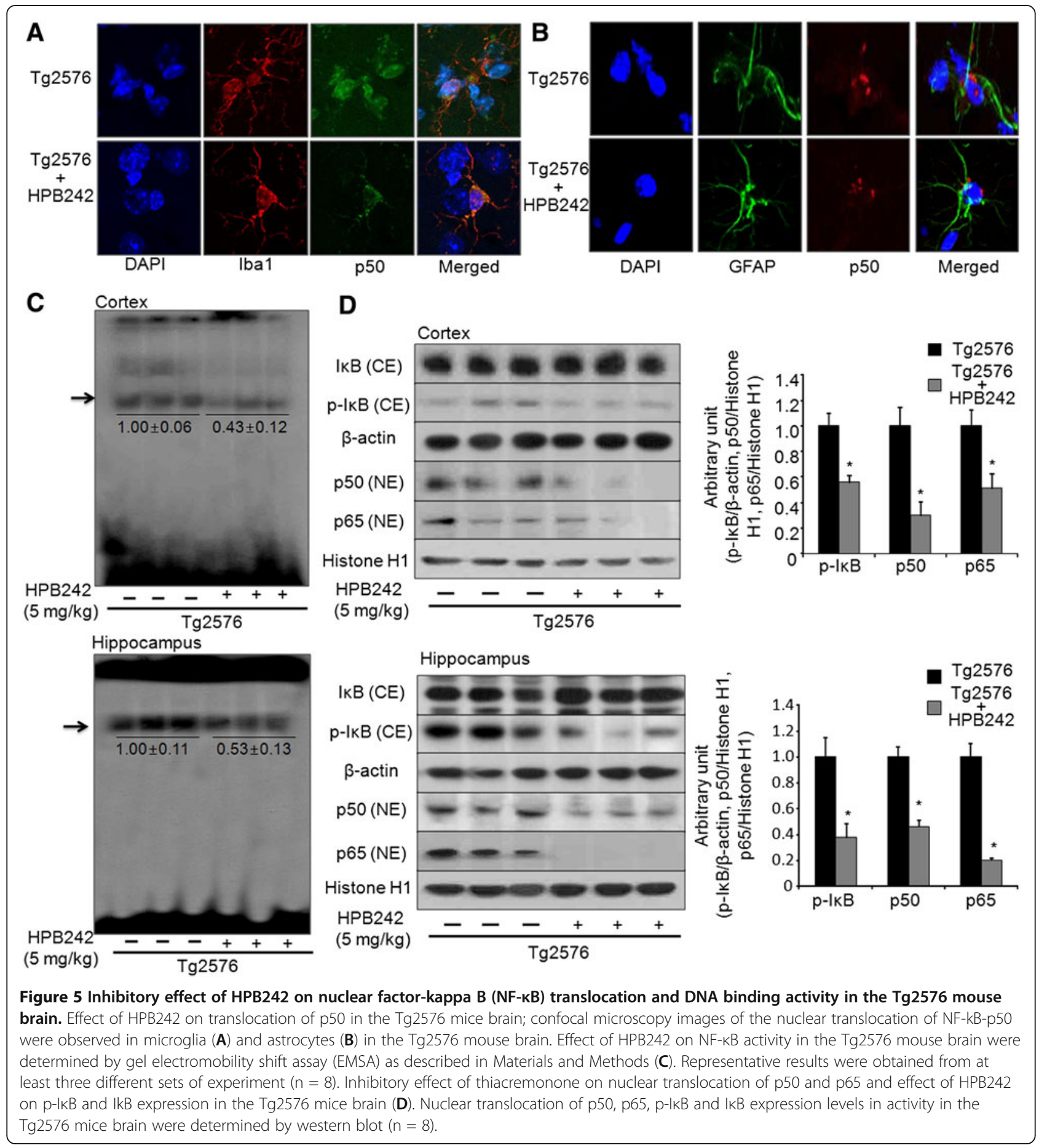

$\mathrm{APP} / \mathrm{PS} 1$ is an AD mouse model bearing mutant transgenes of APP and PS1; A $\beta$ deposition and neuroinflammation were present in this mouse model in the early stage of life $[39,40]$. We also reported that Tg2576 mice displayed $A \beta$ deposition, neuronal dysfunction, neuroinflammation and impairment of spatial memory by overexpression of APP [41]. Furthermore, neuroinflammatory reaction has been detected in $A \beta$-infused mice [42,43]. It was also reported that several antiinflammatory compounds such as 4-O-methylhonokiol, thiacremonone and obovatol improved memory functions in $\mathrm{AD}$ animal models $[6,12,42]$. In the present study HPB242 inhibited memory impairment, and suppressed amyloidogenesis via its anti-neuroinflammatory properties in $\mathrm{Tg} 2576$ mice. These results indicated that anti-neuroinflammatory effects of HPB242 could be 


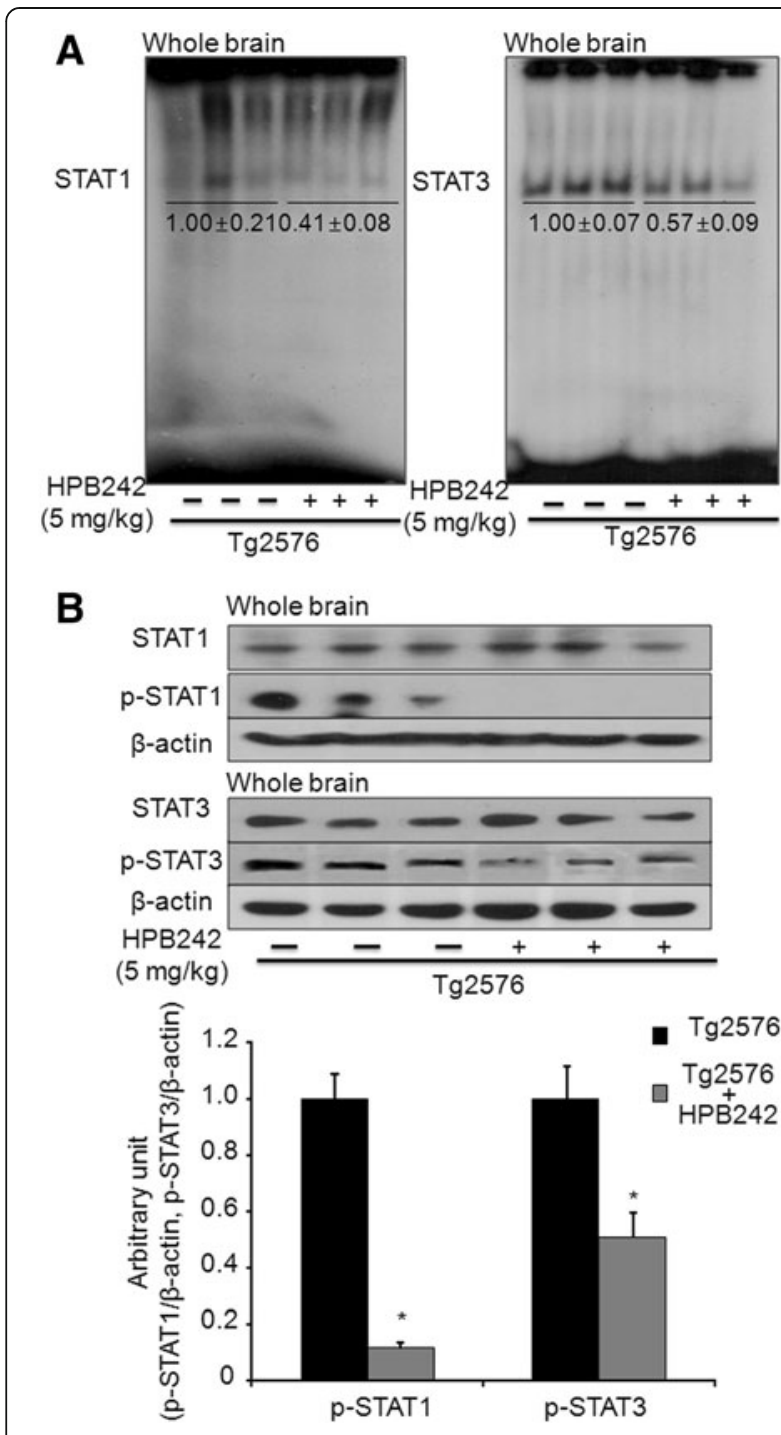

Figure 6 Effects of HPB242 on signal transducer and activator of transcription (STAT) 1 and STAT3 activation in the Tg2576 mice. Gel electromobility shift assay (EMSA) analysis of STAT1 and STAT3 DNA binding activity in nuclear extracts from the brains (cortex and hippocampus) of HPB242-treated and non-treated Tg2576 mice(A). The retarded bands are indicated by an arrow. Representative results were obtained from at least three different sets of experiment $(n=8)$. The Tg2576 mouse brain extracts were prepared, and phospho-STAT1 and phospho-STAT3 level were detected by western blot (B). Each blot was representative of three experiments $(n=8)$.

associated with anti-amyloidgenesis, and thus improve memory dysfunction.

BACE1 cleaves APP at the N-terminal position of A $\beta$ [44]. It was reported that the Swedish mutant $\operatorname{Tg} 2576$ mice show enhanced cleavage of APP by increase of $\beta$-secretase activation [45]. It is known that $A \beta$ is generated from APP by a series of proteolytic processes involving $\beta$ - and $\gamma$-secretases in the amyloidogenic pathway [46]. In the present study, we found that HPB242 reduced $\mathrm{A} \beta$ accumulation in $\operatorname{Tg} 2576$ mice through inhibition of $\beta$-secretase activity and consecutive decrease in expression of APP and C99. Recently, it was also reported that the anti-inflammatory compound, thiacremonone, a sulfur compound isolated from garlic, and 4-O-methylhonokiol effectively inhibited amyloidogenesis through reduced $\beta$-secretase activity in LPS-injected mice [12,47]. Activated astrocytes and microglia closely associate to amyloid plaques in AD. They could have a role in the neurotoxicity observed in $A D$ because of the inflammatory reaction they generate [48]. BACE1 is induced in the proximity of activated astrocytes and microglia and upregulated in astrocytes and microglia upon exposure to pro-inflammatory cytokines influencing APP processing and $\beta$-secretase activity, to induce amyloidogenesis $[49,50]$. We found that the number of reactive astrocytes and microglia were elevated in the brain of $\operatorname{Tg} 2576$ mice, which was prevented by HPB242. HPB242 also demonstrated antiinflammatory and anti-amyloidogenic effects in the Tg2576 mouse brain. Similar to these in vitro effects of HPB242-like anti-inflammatory and anti-amyloidogenic effects [10], it was also reported that BACE1 transcription is increased by other inflammatory gene expression such as iNOS and COX-2, which are regulated by NF- $\mathrm{kB}$ in reactive astrocytes and microglia [51]. In this study, we also found that HPB242 inhibits expression iNOS and COX-2, especially in the hippocampus of $\mathrm{Tg} 2576$ mice. Moreover, we found that the reactive cell number for GFAP and Iba1 are also reactive for p50, and the elevated co-reactive cell numbers in the $\mathrm{Tg} 2576$ mouse brain was reduced by HPB242. These results suggest that the inhibitory effect of HPB242 on the activation of astrocytes and microglia might be significant to modulate or halt neuroinflammatory-mediated amyloidogenesis.

$\mathrm{NF}-\mathrm{kB}$ is a positive regulator in the expression of a variety of rapid-response genes involved in inflammatory effects and amyloidogenesis [52]. NF- $\mathrm{kB}$ activates the transcription of APP, BACE1 and some of the $\gamma$-secretase members and increases protein expressions and enzymatic activities, resulting in enhanced $A \beta$ production [53]. We therefore investigated the activity of NF- $\mathrm{KB}$ as a possible mechanism of the anti-inflammatory and anti-amyloidogenesis effect of HPB242. In this study we showed that HPB242 reduced NF- $\mathrm{KB}$ activity in the $\operatorname{Tg} 2576$ mouse brain. In fact, in the previous in vitro studies, we found that HPB242 prevented LPS-induced neuroinflammation and amyloidogenesis in cultured astrocytes and microglia through inactivation of NF- $\kappa B$ [10]. In addition, numerous factors were reported to inhibit amyloidogenesis via suppression of NF- $\mathrm{kB}$ such as sorafenib [54], L-theanine [55] and tripchlorolide [56]. Further support comes from a previous study showing that in $\mathrm{AD}$ the brain 
contains increased levels of BACE1, C99 and NF-kB, and $\mathrm{NF}-\mathrm{KB}$ expression leads to increase of BACE1 promoter activity and BACE1 transcription, while knockout of NF- $\kappa B$ decreases BACE1 gene expression in LPS-injected mice [6]. Moreover, in the present study, we also found that p50 and p65 subunits of NF- $\mathrm{kB}$ are translocated into the nucleus of astrocytes and microglia in the brains of $\operatorname{Tg} 2576$ mice, and then the translocation of p50 and p65 are inhibited by the treatment of HPB242. It was reported that $A \beta$ activated the NF- $\mathrm{B} B$ pathway by selectively inducing the nuclear translocation of the p50 and p65 subunits, and promoted an apoptotic profile of gene expression [19]. Consistent with the effects on amyloidogenesis as well as C99 and BACE1 expression, NF- $\kappa$ B-induced increase in $\beta$-secretase activity was also prevented by HPB242. Therefore, inhibiting the effect of NF- $\mathrm{kB}$ could be significant in the anti-inflammatory and anti-amyloidogenic effect of HPB242.

STAT1/3 may also be activated in glial cells by a number of cytokines and then translocated from the cytosol to the nucleus [57]. In the nucleus, STATs regulate the activity of genes whose products are critical in controlling $\beta$-secretase activity [58]. STAT1/3 is transcriptionally activated by binding to the STAT $1 / 3$ binding sequence in the BACE1 promoter region; it is interesting to note that a number of transcription factor binding sites become activated in response to $A \beta$ generation [45]. It has been reported that a humanin (HN) derivative named colivelin completely restored cognitive function in $\operatorname{Tg} 2576$ mice by activating the STAT3 [29]. In this study, we showed that HPB242 inhibited phosphorylation of STAT1/3 as well as DNA binding activity. In fact, in the previous studies we also found that blocking STAT3 abolished the inhibitory effect of HPB242 on NF- $\kappa B$ and amyloidogenesis induced by LPS [10]. Additionally, endogenous BACE1 levels were decreased by overexpression of SOCS, an endogenous negative regulator of STAT1 signaling [26], demonstrating that downregulation of STAT1 signaling suppresses BACE1 expression and $A \beta$ generation in neurons [27]. These findings suggest that one mechanism by which HPB242 prevents anti-amyloidogenesis is due to a decrease in phosphorylation of STAT1 and STAT3. In conclusion, our data showed that HPB242 can protect Tg2576 mice from memory impairment through inhibition of NF- $\mathrm{kB}$ and STAT1/3, which could result in the inhibition of $A \beta_{1-42}$ accumulation by attenuating $\beta$-secretase activity. We suggest that HPB242, a new product from a tyrosine-fructose MR, could be useful for treatment and/or prevention of neuroinflammatory diseases such as AD.

\section{Abbreviations}

AD: Alzheimer's disease; AB: Amyloid-beta; ANOVA: Analysis of variance; APP: Amyloid precursor protein; BACE1: Beta-secretase 1;

COX-2: cyclooxygenase-2; DCM: Dichloromethane; ECL: Enhanced chemiluminescence; EDTA: Ethylenediamine tetraacetic acid anticoagulant; EGCG: (-)-epigallocatechin-3-gallate; ELISA: Enzyme-linked immunosorbent assay; EMSA: Gel electromobility shift assay; EtOAcL: Ethyl acetate; GFAP: Glial fibrillary acidic protein; HPB242: 2,4-bis(p-hydroxyphenyl)-2-butenal; Iba1: Ionized calcium binding adaptor molecule 1; IKB: Inhibitor of KB; iNOS: Inducible nitric oxide synthase; LPS: Lipopolysaccharide; MR: Maillard reaction; MeOH: Methanol; NF-kB: Nuclear factor-kappa B; PBS: Phosphatebuffered saline; PS1: Presenilin1; SEM: Standard error of the mean; SOCS: Suppressor of cytokine signaling; STAT1/3: Signal transducer and activator of transcription $1 / 3$.

\section{Competing interests}

The authors declare that they have no competing interests.

\section{Authors' contributions}

J-TH designed the study and prepared the manuscript. PJ and J-A K performed experiments. $\mathrm{H}$-SJ isolated and characterized 2,4-bis(phydroxyphenyl)-2-butenal. D-YC and Y-JL discussed the study. All authors have read and approved the final version of this manuscript.

\section{Acknowledgements}

This work was supported by a grant from the National Research Foundation of Korea (NRF) funded by the Korean Government (MEST; MRC, 20110029480), by a grant (A101836) from the Korean Health Technology R\&D Project, Ministry for Health, Welfare and Family Affairs, Republic of Korea and by the Priority Research Centers Program through the NRF funded by the Ministry of Education, Science and Technology (2011-0031403).

\section{Author details}

${ }^{1}$ College of Pharmacy, Chungbuk National University, 12 Gaesin-dong, Heungduk-gu, Cheongju, Chungbuk 361-763, Korea. ${ }^{2}$ Medical Research Center, Chungbuk National University, 12 Gaesin-dong, Heungduk-gu, Cheongju, Chungbuk 361-763, Korea. ${ }^{3}$ College of Agriculture, Life and Environments Sciences, Chungbuk National University, 12, Gaeshin-dong, Heungduk-gu, Cheongju, Chungbuk 361-763, Korea. ${ }^{4}$ College of Pharmacy, Yeungnam University, Gyeongsan, Gyeongbuk 712-749, Republic of Korea.

${ }^{5}$ School of Equine industries, Cheju Halla University, 38 Halladaehak-ro, Jeju 690-708, Korea.

Received: 19 September 2012 Accepted: 23 December 2012

Published: 5 January 2013

\section{References}

1. Watts JC, Giles K, Grillo SK, Lemus A, DeArmond SJ, Prusiner SB: Bioluminescence imaging of $A \beta$ deposition in bigenic mouse models of Alzheimer's disease. Proc Natl Acad Sci USA 2011, 108:2528-2533.

2. Wang HY, Bakshi K, Frankfurt M, Stucky A, Goberdhan M, Shah SM, Burns LH: Reducing amyloid-related Alzheimer's disease pathogenesis by a small molecule targeting filamin A. J Neurosci 2012, 32:9773-9784.

3. So PP, Zeldich E, Seyb Kl, Huang MM, Concannon JB, King GD, Chen CD, Cuny GD, Glicksman MA, Abraham CR: Lowering of amyloid beta peptide production with a small molecule inhibitor of amyloid-beta precursor protein dimerization. Am J Neurodegener Dis 2012, 1:75-87.

4. Tuppo EE, Arias HR: The role of inflammation in Alzheimer's disease. Int J Biochem Cell Biol 2005, 37:289-305.

5. Orellana DI, Quintanilla RA, Maccioni RB: Neuroprotective effect of TNFalpha against the beta-amyloid neurotoxicity mediated by CDK5 kinase. Biochim Biophys Acta 2007, 1773:254-263.

6. Lee YJ, Choi DY, Choi IS, Kim KH, Kim YH, Kim HM, Lee K, Cho WG, Jung JK, Han SB, Han JY, Nam SY, Yun YW, Jeong JH, Oh KW, Hong JT: Inhibitory effect of 4-O-methylhonokiol on lipopolysaccharide-induced neuroinflammation, amyloidogenesis and memory impairment via inhibition of nuclear factor-kappaB in vitro and in vivo models. J Neuroinflammation 2012, 9:35.

7. Cho HJ, Kim SK, Jin SM, Hwang EM, Kim YS, Huh K, Mook-Jung I: IFNgamma-induced BACE1 expression is mediated by activation of JAK2 and ERK1/2 signaling pathways and direct binding of STAT1 to BACE1 promoter in astrocytes. Glia 2007, 55:253-262.

8. Heneka MT, O'Banion MK: Inflammatory processes in Alzheimer's disease. J Neuroimmunol 2007, 184:69-91. 
9. Sastre M, Dewachter I, Landreth GE, Willson TM, Klockgether T, van Leuven F, Heneka MT: Nonsteroidal anti-inflammatory drugs and peroxisome proliferator-activated receptor-gamma agonists modulate immunostimulated processing of amyloid precursor protein through regulation of beta-secretase. J Neurosci 2003, 23:9796-9804.

10. Lee YJ, Choi DY, Choi IS, Han JY, Jeong HS, Han SB, Oh KW, Hong JT: Inhibitory effect of a tyrosine-fructose Maillard reaction product, 2,4-bis (p-hydroxyphenyl)-2-butenal on amyloid-beta generation and inflammatory reactions via inhibition of NF-kappaB and STAT3 activation in cultured astrocytes and microglial BV-2 cells. J Neuroinflammation 2011, 8:132

11. Finnie JW, Blumbergs PC, Williamson MM: Alzheimer type II astrocytes in the brains of pigs with salt poisoning (water deprivation/intoxication). Aust Vet J 2010, 88:405-407.

12. Lin GH, Lee YJ, Choi DY, Han SB, Jung JK, Hwang BY, Moon DC, Kim Y Lee MK, Oh KW, Jeong HS, Leem JY, Shin HK, Lee JH, Hong JT: Antiamyloidogenic effect of thiacremonone through anti-inflamation in vitro and in vivo models. J Alzheimers Dis 2012, 29:659-676.

13. Korolainen MA, Auriola S, Nyman TA, Alafuzoff I, Pirttila T: Proteomic analysis of glial fibrillary acidic protein in Alzheimer's disease and aging brain. Neurobiol Dis 2005, 20:858-870.

14. Cai Y, Zhang XM, Macklin LN, Cai H, Luo XG, Oddo S, Laferla FM, Struble RG, Rose GM, Patrylo PR, Yan XX: BACE1 elevation is involved in amyloid plaque development in the triple transgenic model of Alzheimer's disease: differential $A \beta$ antibody labeling of early-onset axon terminal pathology. Neurotox Res 2012, 21:160-174

15. Jekabsone A, Mander PK, Tickler A, Sharpe M, Brown GC: Fibrillar betaamyloid peptide Abeta1-40 activates microglial proliferation via stimulating TNF-alpha release and $\mathrm{H} 2 \mathrm{O} 2$ derived from NADPH oxidase: a cell culture study. J Neuroinflammation 2006, 3:24.

16. Strohmeyer R, Kovelowski CJ, Mastroeni D, Leonard B, Grover A, Rogers J: Microglial responses to amyloid beta peptide opsonization and indomethacin treatment. J Neuroinflammation 2005, 2:18.

17. Kakimura J, Kitamura Y, Takata K, Umeki M, Suzuki S, Shibagaki K, Taniquchi T, Nomura Y, Gebicke-Haerter PJ, Smith MA, Perry G, Shimohama S: Microglial activation and amyloid-beta clearance induced by exogenous heat-shock proteins. FASEB J 2002, 16:601-603.

18. Jin M, Suh SJ, Yang JH, Lu Y, Kim SJ, Kwon S, Jo TH, Kim JW, Park Yl, Ahn GW, Lee CK, Kim CH, Son JK, Son KH, Chang HW: Anti-inflammatory activity of bark of Dioscorea batatas DECNE through the inhibition of iNOS and COX-2 expressions in RAW264.7 cells via NF-kappaB and ERK1/ 2 inactivation. Food Chem Toxicol 2010, 48:3073-3079.

19. Valerio A, Boroni F, Benarese M, Sarnico I, Ghisi V, Bresciani LG, Ferrario M, Borsani G, Spano P, Pizzi M: NF-kappaB pathway: a target for preventing beta-amyloid $(A \beta)$-induced neuronal damage and $A \beta 42$ production. Eur J Neurosci 2006, 23:1711-1720.

20. Chen $\mathrm{CH}$, Zhou W, Liu S, Deng $Y$, Cai F, Tone M, Tone $Y$, Tong $Y$, Song W: Increased NF-kappaB signalling up-regulates BACE1 expression and its therapeutic potential in Alzheimer's disease. Int J Neuropsychopharmacol 2011, 15:77-90.

21. $\mathrm{Na}$ CH, Jeon $\mathrm{SH}$, Zhang G, Olson GL, Chae CB: Inhibition of amyloid betapeptide production by blockage of beta-secretase cleavage site of amyloid precursor protein. J Neurochem 2007, 101:1583-1595.

22. Lee JW, Lee YK, Ban JO, Ha TY, Yun YP, Han SB, Oh KW, Hong JT: Green tea (-)-epigallocatechin-3-gallate inhibits beta-amyloidinduced cognitive dysfunction through modification of secretase activity via inhibition of ERK and NF-kappaB pathways in mice. J Nutr 2009, 139:1987-1993.

23. Wen Y, Yu WH, Maloney B, Bailey J, Ma J, Marie I, Maurin T, Wang L, Figueroa $H$, Herman M, Krishnamurthy P, Liu L, Planel E, Lau LF, Lahiri DK, Duff K: Transcriptional regulation of beta-secretase by $\mathrm{p} 25 / \mathrm{cdk} 5$ leads to enhanced amyloidogenic processing. Neuron 2008, 57:680-690.

24. Hagihara K, Nishikawa T, Sugamata Y, Song J, Isobe T, Taga T, Yoshizaki K: Essential role of STAT3 in cytokine-driven NF-kappaB-mediated serum amyloid A gene expression. Genes Cells 2005, 10:1051-1063.

25. Capiralla $H$, Vingtdeux $V$, Zhao $H$, Sankowski $R$, Al-Abed $Y$, Davies $P$, Marambaud P: Resveratrol mitigates lipopolysaccharide- and $A \beta$ mediated microglial inflammation by inhibiting the TLR4/NF-kappaB/ STAT signaling cascade. J Neurochem 2012, 120:461-472.

26. Kile BT, Alexander WS: The suppressors of cytokine signalling (SOCS) Cell Mol Life Sci 2001, 58:1627-1635.
27. Cho HJ, Jin SM, Son SM, Kim YW, Hwang JY, Hong HS, Mook-Jung I: Constitutive JAK2/STAT1 activation regulates endogenous BACE1 expression in neurons. Biochem Biophys Res Commun 2009, 386:175-180.

28. Wan J, Fu AK, Ip FC, Ng HK, Hugon J, Page G, Wang JH, Lai KO, Wu Z, Ip NY: Tyk2/STAT3 signaling mediates beta-amyloid-induced neuronal cell death: implications in Alzheimer's disease. J Neurosci 2010, 30:6873-6881

29. Chiba T, Yamada M, Sasabe J, Terashita K, Shimoda M, Matsuoka M, Aiso S: Amyloid-beta causes memory impairment by disturbing the JAK2/STAT3 axis in hippocampal neurons. Mol Psychiatry 2009, 14:206-222.

30. Kundinger MM, Zabala-Diaz IB, Chalova VI, Ricke SC: Effects of Maillard reaction products on hilA expression in Salmonella typhimurium. J Food Sci 2008, 73:M32-35.

31. Morales FJ, Babbel MB: Antiradical efficiency of Maillard reaction mixtures in a hydrophilic media. J Agric Food Chem 2002, 50:2788-2792.

32. Yen GC, Tsai LC, Lii JD: Antimutagenic effect of Maillard browning products obtained from amino acids and sugars. Food Chem Toxicol 1992, 30:127-132

33. Hsiao K, Chapman P, Nilsen S, Eckman C, Harigaya Y, Younkin S, Yang F, Cole G: Correlative memory deficits, Abeta elevation, and amyloid plaques in transgenic mice. Science 1996, 274:99-102.

34. Hwang IG, Kim HY, Woo KS, Hong JT, Hwang BY, Jung JK, Lee J, Jeong HS Isolation and characterisation of an a-glucosidase inhibitory substance from fructose-tyrosine Maillard reaction products. Food Chem 2011, 127:122-126.

35. Morris R: Developments of a water-maze procedure for studying spatial learning in the rat. J Neurosci Methods 1984, 11:47-60.

36. Veerhuis R: Histological and direct evidence for the role of complement in the neuroinflammation of AD. Curr Alzheimer Res 2011, 8:34-58.

37. McGeer EG, McGeer PL: Inflammatory processes in Alzheimer's disease. Prog Neuropsychopharmacol Biol Psychiatry 2003, 27:741-749.

38. Eikelenboom P, Bate C, Van Gool WA, Hoozemans JJ, Rozemuller JM, Veerhuis R, Williams A: Neuroinflammation in Alzheimer's disease and prion disease. Glia 2002, 40:232-239.

39. Ruan L, Kang Z, Pei G, Le Y: Amyloid deposition and inflammation in APPswe/PS1dE9 mouse model of Alzheimer's disease. Curr Alzheimer Res 2009, 6:531-540

40. Puli L, Pomeshchik Y, Olas K, Malm T, Koistinaho J, Tanila H: Effects of human intravenous immunoglobulin on amyloid pathology and neuroinflammation in a mouse model of Alzheimer's disease. J Neuroinflammation 2012, 9:105.

41. Lee YJ, Choi DY, Han SB, Kim YH, Kim KH, Hwang BY, Kang JK, Lee BJ, Oh $\mathrm{KW}$, Hong JT: Inhibitory effect of ethanol extract of Magnolia officinalis on memory impairment and amyloidogenesis in a transgenic mouse model of Alzheimer's disease via regulating beta-secretase activity. Phytother Res 2012, 10:4643.

42. Choi DY, Lee JW, Peng J, Lee YJ, Han JY, Lee YH, Choi IS, Han SB, Jung JK, Lee WS, Lee SH, Kwon BM, Oh KW, Hong JT: Obovatol improves cognitive functions in animal models for Alzheimer's disease. J Neurochem 2012, 120:1048-1059.

43. Lee YK, Choi IS, Ban JO, Lee HJ, Lee US, Han SB, Jung JK, Kim YH, Kim KH, Oh KW, Hong JT: 4-O-methylhonokiol attenuated beta-amyloid-induced memory impairment through reduction of oxidative damages via inactivation of p38 MAP kinase. J Nutr Biochem 2011, 22:476-486.

44. Sastre M, Walter J, Gentleman SM: Interactions between APP secretases and inflammatory mediators. J Neuroinflammation 2008, 5:25.

45. Cole SL, Vassar R: The Alzheimer's disease beta-secretase enzyme, BACE1. Mol Neurodegener 2007, 2:22

46. Vassar R: BACE1: the beta-secretase enzyme in Alzheimer's disease. J Mol Neurosci 2004, 23:105-114.

47. Lee YJ, Choi DY, Yun YP, Han SB, Kim HM, Lee K, Choi SH, Yang MP, Jeon $\mathrm{HS}$, Jeong $\mathrm{JH}$, Oh KW, Hong JT: Ethanol extract of magnolia officinalis prevents lipopolysaccharide-induced memory deficiency via its antineuroinflammatory and antiamyloidogenic effects. Phytother Res 2012, $10: 4740$

48. von Bernhardi R, Ramirez G: Microglia-astrocyte interaction in Alzheimer's disease: friends or foes for the nervous system? Biol Res 2001, 34:123-128.

49. Heneka MT, Sastre M, Dumitrescu-Ozimek L, Dewachter I, Walter J, Klockgether T, Van Leuven F: Focal glial activation coincides with increased BACE1 activation and precedes amyloid plaque deposition in APP[V717I] transgenic mice. J Neuroinflammation 2005, 2:22. 
50. Yamamoto M, Kiyota T, Horiba M, Buescher JL, Walsh SM, Gendelman HE, Ikezu T: Interferon-gamma and tumor necrosis factor-alpha regulate amyloid-beta plaque deposition and beta-secretase expression in Swedish mutant APP transgenic mice. Am J Pathol 2007, 170:680-692.

51. Bourne KZ, Ferrari DC, Lange-Dohna C, Rossner S, Wood TG, Perez-Polo JR: Differential regulation of BACE1 promoter activity by nuclear factorkappaB in neurons and glia upon exposure to beta-amyloid peptides. J Neurosci Res 2007, 85:1194-1204.

52. Sambamurti K, Kinsey R, Maloney B, Ge YW, Lahiri DK: Gene structure and organization of the human beta-secretase (BACE) promoter. FASEB J 2004, 18:1034-1036.

53. Chami L, Buggia-Prevot V, Duplan E, Delprete D, Chami M, Peyron JF, Checler F: Nuclear factor-kappaB Regulates betaAPP and beta- and gamma-secretases differently at physiological and supraphysiological abeta concentrations. J Biol Chem 2012, 287:24573-24584.

54. Echeverria V, Burgess S, Gamble-George J, Zeitlin R, Lin X, Cao C, Arendash GW: Sorafenib inhibits nuclear factor kappa B, decreases inducible nitric oxide synthase and cyclooxygenase-2 expression, and restores working memory in APPswe mice. Neuroscience 2009, 162:1220-1231.

55. Kim TI, Lee YK, Park SG, Choi IS, Ban JO, Park HK, Nam SY, Yun YW, Han SB, Oh KW, Hong JT: I-Theanine, an amino acid in green tea, attenuates betaamyloid-induced cognitive dysfunction and neurotoxicity: reduction in oxidative damage and inactivation of ERK/p38 kinase and NF-kappaB pathways. Free Radic Biol Med 2009, 47:1601-1610.

56. Pan XD, Chen XC, Zhu YG, Chen LM, Zhang J, Huang TW, Ye QY, Huang HP: Tripchlorolide protects neuronal cells from microglia-mediated betaamyloid neurotoxicity through inhibiting NF-kappaB and JNK signaling. Glia 2009, 57:1227-1238.

57. Kitamura Y, Shimohama S, Ota T, Matsuoka Y, Nomura Y, Taniguchi T: Alteration of transcription factors NF-kappaB and STAT1 in Alzheimer's disease brains. Neurosci Lett 1997, 237:17-20.

58. Fagerlund R, Melen K, Cao X, Julkunen I: NF-kappaB p52, RelB and c-Rel are transported into the nucleus via a subset of importin alpha molecules. Cell Signal 2008, 20:1442-1451.

doi:10.1186/1742-2094-10-2

Cite this article as: Jin et al:: Anti-inflammatory and anti-amyloidogenic effects of a small molecule, 2,4-bis(p-hydroxyphenyl)-2-butenal in Tg2576 Alzheimer's disease mice model. Journal of Neuroinflammation 2013 10:2.

\section{Submit your next manuscript to BioMed Central and take full advantage of:}

- Convenient online submission

- Thorough peer review

- No space constraints or color figure charges

- Immediate publication on acceptance

- Inclusion in PubMed, CAS, Scopus and Google Scholar

- Research which is freely available for redistribution 